DOI https://doi.org/10.18551/rjoas.2017-06.01

\title{
THE IMPACT OF SERVICE VARIETY ON ORGANIZATIONAL STRUCTURE IN A HETEROGENEOUS SECTOR: A REGRESSION ANALYSIS OF GERMAN RETAIL HORTICULTURE
}

\author{
Engelke Christian \\ Friedrich-Bach-Str. 29, 31675 Bückeburg, Germany \\ E-mail: c.engelke@engel-engelke.de
}

\begin{abstract}
Structural change towards services becomes exigent when the sales do not meet operational direction anymore. Thus, the a priori strong heterogeneity in German retail horticulture $(\mathrm{GRH})$ requires knowledge in the interaction of relevant internal parameters to find the best individual combination. On this account, the present paper has two goals: First, to systematise relevant, internal characteristics (contingency), considering previous research, by running a confirmatory factor analysis. Second, we investigate the impact of the service variety on the organizational structure and economic parameters, in order to find the right combination for $\mathrm{GRH}$ by running regression analysis. Based on a previous exploratory study, 283 retail nurseries were asked questions in an online survey and their answers were interpreted in a quantitative way. Part 1: We gave proof that relevant situational characteristics on GRH include size, level of controlling, experience and service variety as internal factor variables, showing high eigenvalues. Part 2: We found causal relationships between the service variety and the number of hierarchy, span of control and hierarchy configuration (H1). The size is also of significant importance but on a minor level. Size faces positive correlation on delegation $(\mathrm{H} 2)$, and the size and the level of controlling also have adequate impact on the sales volume. Meanwhile the configuration variables have no impact on the sales volume. This means that sales volume is related to the size and the level of controlling but independent of the configuration. Accordingly, there is no coordinated interaction of contingency, structure and delegation variables with impact on the sales volumes $(\mathrm{H} 3)$. Structural delegations on sales volume are significantly acquisition/ marketing and planning as operational performance-variables, which are mostly done by the owner/CEO himself. These tasks show negative coefficients, which lead to the proposal that with growing sales, the level of delegation has to be improved and these tasks must be transferred to employees. On this account, central structures focussing on performances, not products, and a low level of departmentalization together make up the ideal organizational structure for GRH.
\end{abstract}

\section{KEY WORDS}

Confirmatory factor analysis, heterogeneity, organizational analysis, regression analysis, services.

In times of structural change, increasing competition, multiple sale channels and a war for talent (Meyerding, 2016), the German horticulture market is exposed to new requirements. Keeping up means turning away from accustomed procedures. The economy of family businesses predominantly originated from crop growing production with wholesaling distribution (Bahnmüller, 2011; BMELV, 2013). Nowadays, procedure and distribution channels have often modified to retail and services, known as retail horticulture. With the traditional heterogeneous structure breaking up, the operational emphasis is being deferred, and a new spectrum of products and services is emerging (Hohengartner, 2016). Most of the horticultural companies are small-medium sized enterprises (SMEs) with an increasing service portfolio (Engelke, 2016) but without adequate management tools (Gabriel \& Bitsch, 2014). This is not limited to German horticulture but can be conferred to European horticulture in general.

The German horticulture ranks with a gross value of $1 \%$ within the German National Economy, whereas the retail sector ranks highest with a gross value of $22 \%$ (Dirksmeyer \& 
Fluck, 2013). There is a gradient from larger companies with higher turnover than smaller companies, and there are also better profits for retail and service companies than other companies (ZBG, 2014). Although German retail horticulture (GRH) has higher consumption per capita on plants and services compared to European retail horticulture (Tröster, 2016), sales volumes are stagnating and decreasing, respectively, which correlates with a decreasing gross income and negative net income (ZBG, 2015). Hence, from an economic view, the future looks dire. The situation becomes exigent when sales does not conform to the operational direction anymore, and structural change is inevitable. When there is economic dissatisfaction, management has to react. As the relevant literature shows, there is a dependency between management skill level and successfully handling change management processes (Wong, 2005 e.g.). The deficiencies of GRH highlight the necessity to investigate organizational structures.

One way to investigate organizational change is to take the contingency approach (CA). This approach identifies the context of the situation to highlight the individual organizational structure. The aim is principally to identify relationships between the dependent variable of organizational structure and the independent variable of contextual situations and use the correlation between the variables to explain the individual organization. Pairing the right structure with the appropriate situation creates the 'fit' (see Figure 1).

Because of previous studies, Kieser (1985) discussed the problem of low correlation, high variances, and highly inexplicable solutions in the CA. This discussion leads to criticism of the CA, because the monocausal view and the lack of relevant variables obscure identification of efficiencies (Kieser, 1985). Despite these fundamental criticisms, there is consensus that the CA is appropriate to explain structural differences because relevant influencing factors and their impact are considered, which can help to optimize internal parameters within the wide spectrum of contingent research (Armbrecht, 1992). The CA helps to structure and orient the organizational system (Kieser \& Kubicek, 1995).

The purpose of the CA differs between authors. While Vahs (2009) \& Kieser (2006) classify the construct as one modern organizational theory that takes a dominant role, others believe the CA is only suitable as a philosophy (Schreyögg, 2003) to build a conceptual framework in organizational studies (Lee, 1989). Even with the different points of view, there is consensus that the CA is one possible approach to analyse an organization and that the CA represents an improvement over previous approaches, such as the bureaucracy model from Weber (Al-Wagdani, 2010). Because of its progression with successive components that enables a holistic view, the CA was chosen for the conceptual framework of the current research.

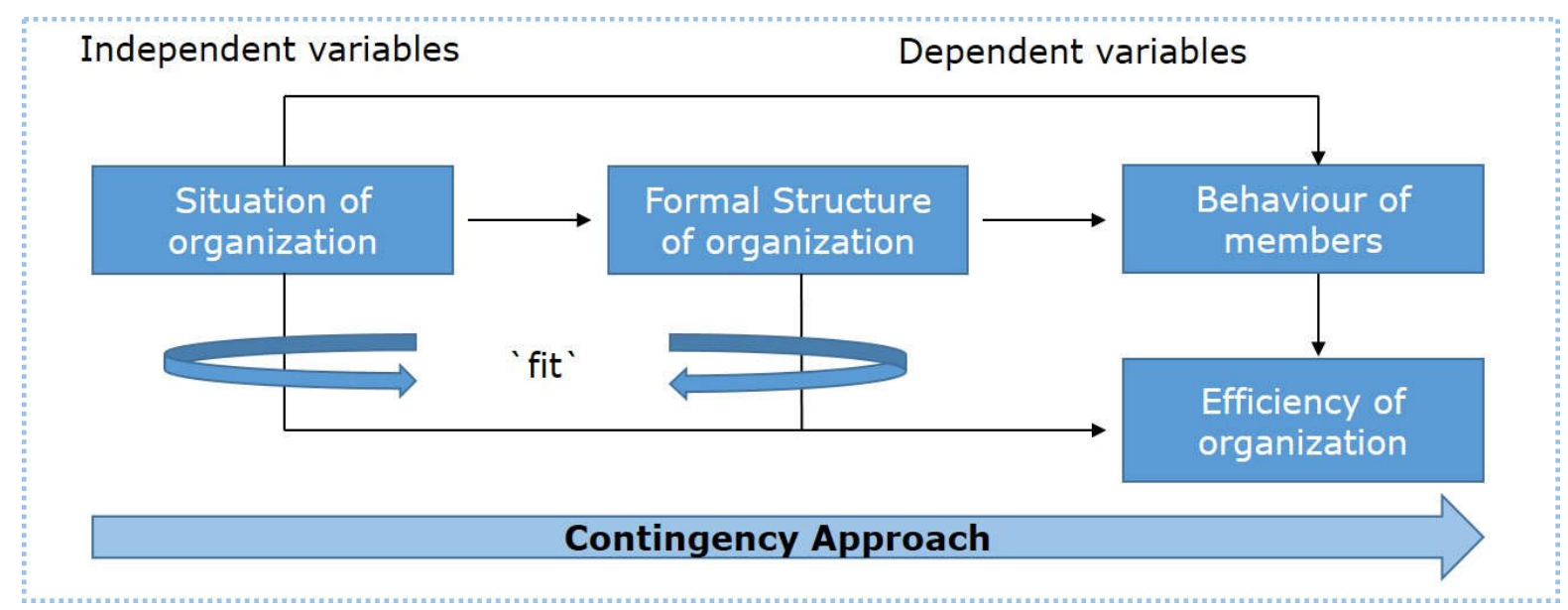

Figure 1 - The analytical model of the contingency approach, in accordance with Vahs (2009), Kieser (1985) and Kubicek \& Wollnik (1975).

Fundamental observations of the CA were made by Hall (1972), Pugh \& Hickson (1968), Pugh, Hickson \& Hinings (1969), and later Auzair (2015). Vahs (2009) summarizes the contextual variables, subdivided as follows: internal variables of enterprise age and 
size, kind of foundation, product portfolio, technology, critical situation, complexity, development stage, and successor establishment; and external variables of competition, customization and the global environment. These factors mainly result from the manufacturing sector; but there is little research on the retail sector and its place in the horticulture market. Böckelmann (1995) highlighted different factors that influence organizational structure in crop production in a study that focused on wholesaling without services. He found that the role (behaviour, leadership) of the entrepreneur is strongly affected by the company size and also the product program, because an extension of the portfolio requires different structure. Schwarz (2008) researched horticultural services and determined their success factors, such as location, employment and organizational efficiency in a study that analysed two individual business lines against GRH with a mix of properties. Therefore, different basic requirements impede to transfer on other branches of trade.

German retail horticulture is faced with structural changes, little knowledge in structural organization available, and an increasing demand on services. The next section describes the relevance of services and the transition to the structural variables in order to formulate the hypotheses.

Different kind of services. Different kinds of services are pure services or added services in combination with the core product (Gann \& Salter, 2000; Lovelock, 1983 e.g.). This bundled package is called a hybrid product. Often, companies start providing services by with added services introduced in their day-to-day business; later, when the business is growing, pure services will follow. Transforming from a producer to a service provider requires a new focus on process organization and organizational structure (Guerrieri \& Meliciani, 2005; Miller, 1982). Departmentalization needs to be improved in order to optimize the division of work. Improving the departmentalization enables the creation of self-contained departments, internal outsourcing and ancillary departments, and external outsourcing (Rainfurth, 2003; Rogelio \& Kellenberg, 2003). Note that GRH is also transforming: it originated as a crop-growing production industry and is now broadening its profile. The compound of the product mix plays a vital role in the structural differences between manufacturing and service companies (Marhaeni \& Nugroho, 2015; Dutta, 1991). For example, heterogeneous enterprises require a better focus on employment and monitoring and differ in size and behaviour (Oi, 1983). Nesheim (1990) agrees and interrelates the characteristics of service management and the organizational design. $\mathrm{He}$ states, for example, that the closer the interaction between the customer and the producer, the more important delegation is. Furthermore, when production and consumption occur simultaneously, flexibility and outsourcing should be increased. Dealing with services automatically also requires the customer integration as central part (Chervonnaya, 2003 e.g.).

There is high diversity in different lines of business, and that is also the case in GRH. Engelke (2013) discovered that the enterprise size and the operational emphasis are variables that influence the service portfolio. In contrast to pure retail companies, service companies show a superior span of control, lower control intensity, higher formalisation and divisional configuration, with superior departmentalization and level of controlling. In a health service survey, Da-Cruz et al. (2011) identified the location, the size, the specific request and the offers on the local surroundings (competition) as influencing factors in service lines, especially in companies with a heterogeneous product portfolio (Hahn \& Taylor, 1990). An increasing product / service portfolio takes the risk of complexity within the organizational structure (Jacobs and Swink, 2011 e.g.), and the companies have to find their individual constellation, which is part of the service management (Kellog, 1995) and which requires an adequate service controlling (Thompson, 1997).

Transition to the structural variables. As mentioned, GRH is characterized by heterogeneous structures. When talking about the individual organization, this research must take the characteristics of SME into account, as most of the GRH businesses fall into this category (Reymann, 2009). Compared to larger firms, Hutzschenreuter (2009) specifies the liability of smallness, which often has a flat structure with little hierarchy, few management control systems and a low degree of functional organization. He also 
mentions the liability of informality (an absence of formal structure and low level of standardization) and finally the ownership and management (see also Deimel, 2008). The latest will be described in hypothesis 2 .

In organizational analyses, the whole organization cannot be surveyed, so an extract must be selected (e.g., Titscher, Meyer \& Mayrhofer, 2008). Different definitions of an organization can be analysed from various perspectives, such as structuring, so there is a heterogeneous field. The consensus is that an organization is defined through specific purposes, regulations and stable borders, as central units of the institutional organization (Schreyögg, 2003 e.g.). Referring to the literature review, the current paper focusses on the structural variables as follows:

- Configuration ('organigram': span of control, control intensity, hierarchy, hierarchy configuration);

- Specialisation (departmentalization);

- Flexibility;

- Centralisation and delegation of tasks.

This research focuses on configuration and specialisation in order to picture the staffing. Flexibility shows the number of departments where the staff is applied. Delegation shows the allocation of tasks. The literature reviews much research in the interaction with hierarchy and span of control. Keren \& Levhari (1979) state that with decreasing levels of hierarchy, the span of control increases, as there is more staff for each supervisor to manage. But the differences shrink when other determinants accrue, such as task characteristics, management principles, organizational arrangements and human resources (e.g. Schulte-Zurhausen, 2005). This goes along with different lines of businesses (Theobald \& Nicholson-Scrotty, 2005).

Research on GRH is rare and has studied the following elements: Success factors (Schwarz, 2008), customer satisfaction (Schöps, 2013), risk management (Von Allwörden, 2005), characteristics, weakness and strengths (BMELV, 2013; Bahnmüller \& Hintze, 2003, to name a few), assortment (Menrad, 2008), controlling application (Gabriel \& Bitsch, 2016; Lentz, 2008), statistics (Dirksmeyer \& Fluck, 2013) and intercompany comparison (ZBG, 2015).

This study seeks to explore the effects of certain structural configurations on GRH with regard for the internal variables. Former studies have often resulted in low significance levels of correlation. It is odd that size, a major variable, is only seldom acknowledged in contingency approaches on SMEs (Chenhall, 2003).

Recapitulating, that internal factors, such as the product portfolio (Vahs, 2009), affect the structural organization, there is no safe ground, if and in which way the services do. We know, that servicing requires to consider specifics, particularly the uno-actu-principle, intangibility, influence of customer (Choi, Nazareth \& Jain, 2010 e.g.), which differs to the manufacturing sector. Getting the fact, that there is an increasing relevance of the services in the companies, and the portfolio are changing, the strong heterogeneity on GRH is accordingly a consequence. Principally, the companies face the risk of complexity when overloading the number of services within the portfolio (Gann \& Salter, 2000), especially when the structural organizational is not customized. Assuming, that the number of services in GRH is increasing in the past (Zentralverband Gartenbau, 2017), and the level of organization is low (Gabriel \& Bitsch, 2014), we formulate:

Hypothesis $1(\mathrm{H1})$ : There is negative correlation between the service variety and the structural organization of $\mathrm{GRH}$.

Research is barren on the topic of the relationship between structural delegation and GRH. In a quantitative study with 104 nurseries, Böckelmann (2005) highlights different factors that influence entrepreneurs, mainly the operation size and the product portfolio. He discovered that the chief executive officer is strongly affected by the size and the product program. Despite the topical nearness, this study focused on wholesaling without services. As mentioned above, ownership and management are of central importance in SMEs and are often integrated in one person. Chandler \& Hanks (1994) describe the owner-manager dominance with concentration of key decisions by the owner himself. With these facts in mind, it appears meaningful to investigate the details of the structural delegation: Which 
tasks are dominated by the owner, and which are delegated to staff. Considering, that an ordinary level of organization requires an adequate level of delegation (Lentz, 2008), this is often not the case in German horticulture (Böckelmann, 2005). If the service variety in fact negatively affects the structural organization (see $\mathrm{H} 1$ ) we conclude, that increasing services have also a negative effect on the level of delegation:

Hypothesis 2 (H2): There is negative correlation between the level of delegation and the service variety.

If there is in fact a possible negative relationship between the service variety and the organizational structure / delegation, there must be also an effect on the sales volume as economic parameter. We know, that in many horticultural companies, the sales volumes are stagnating / decreasing within the last years (ZBG, 2015). This means, that even though the number of services is increasing, there is no economic success. For this reason, we formulate:

Hypothesis 3 (H3): There is negative interaction between the of service variety, structural organization/ delegation and the sales volume.

Despite the popularity of discussing the area of services in the horticultural market, little attention is paid to analysing the internal parameters of $\mathrm{GRH}$. This paper first aims to systematise relevant, internal characteristics (contingency), considering previous research. To approach the problem, we next use regressions to investigate the interrelationship between situation, structure (configuration, delegation) and sales volume.

\section{METHODOLOGY OF RESEARCH}

Sample and procedure. The results of an upstream, exploratory study (Engelke, 2016) were the basis of the current study. The research question of this prior survey was to determine, from the internal perspective, which characteristics distinguish the a priori strong, heterogeneous GRH. Therefore, 64 different characteristics of 7 horticultural companies were collected in an inductive way and later interpreted on the principles of the qualitative content analysis by Mayring (2010) in a previous study. Based on these results, the main study was begun: The first aim was to verify the characteristics of the qualitative prior study in an adjacent quantitative procedure, to find significances. For this purpose, an online survey was conducted among certain companies between February and June of 2015. The email addresses were collected from different sources, such as specialist literature, a register of GRH members, a classified directory of retail nurseries (Taspo, 2010/2011) and personal collecting. Furthermore, an article was published online to support participation. $^{1}$

Deriving the exact number of companies in GRH is difficult because of different lines within the horticulture market (e.g., floristry, ornamental plants and retail nursery) and because of a strong heterogeneity within these lines. The characteristics of $\mathrm{GRH}$, mentioned in section 1, are common in many countries, so this phenomenon is not of Germany but of retail nurseries in general (e.g., Tröster, 2016). The focus of this research was retail nurseries with direct selling and different products and services. Thus, it was important to refine the suitable audience. The following categories were omitted: very small companies (such as floristry shops), as they are retail nurseries only by classification; large retail nurseries, as they are more like garden centres; suspended companies; wholesalers and pure trading companies. During compilation, the addresses were constantly verified, and only those with an email account were chosen. Because of the above-mentioned heterogeneity and, therefore, lack of delimitation between the lines, the literature specifies a number of approximately 10,000 (Dirksmeyer \& Fluck, 2013) to 16,500 companies (Zentralverband Gartenbau e.V., 2017) with a high variance assumed. An effective database of approximately 4,500 current companies was generated. To achieve a large response, it was important to address the owners/CEOs at the opportune time, just before the spring season, which traditionally means the beginning of the peak season with an accordingly heavy workload. Along with the questionnaire, a personal cover letter was

\footnotetext{
${ }^{1}$ GABOT. For discretion, the web address is not listed.
} 
directed to the owner/CEO. A photo of the researcher and background information were included, and to gain favour and credibility, the letter stated that the researcher was the owner of a GRH. The questionnaire was created with the online interface LimeSurvey. The mailing was carried out at the end of February in 2015. After completion, the data were converted, edited and adjusted into IBM SPSS 23/24 for further processing. There were 580 replies, of which 283 respondents thereof filled out the forms completely, resulting in a response rate of $6,3 \%$. This became the basic population of the study. Although the participants were not randomly chosen for the purpose of attaining representative status, they were, nevertheless, a fairly large basic population as a foundation for analysing the research target. Next, the research procedure is illustrated (Figure 2).

Measures:

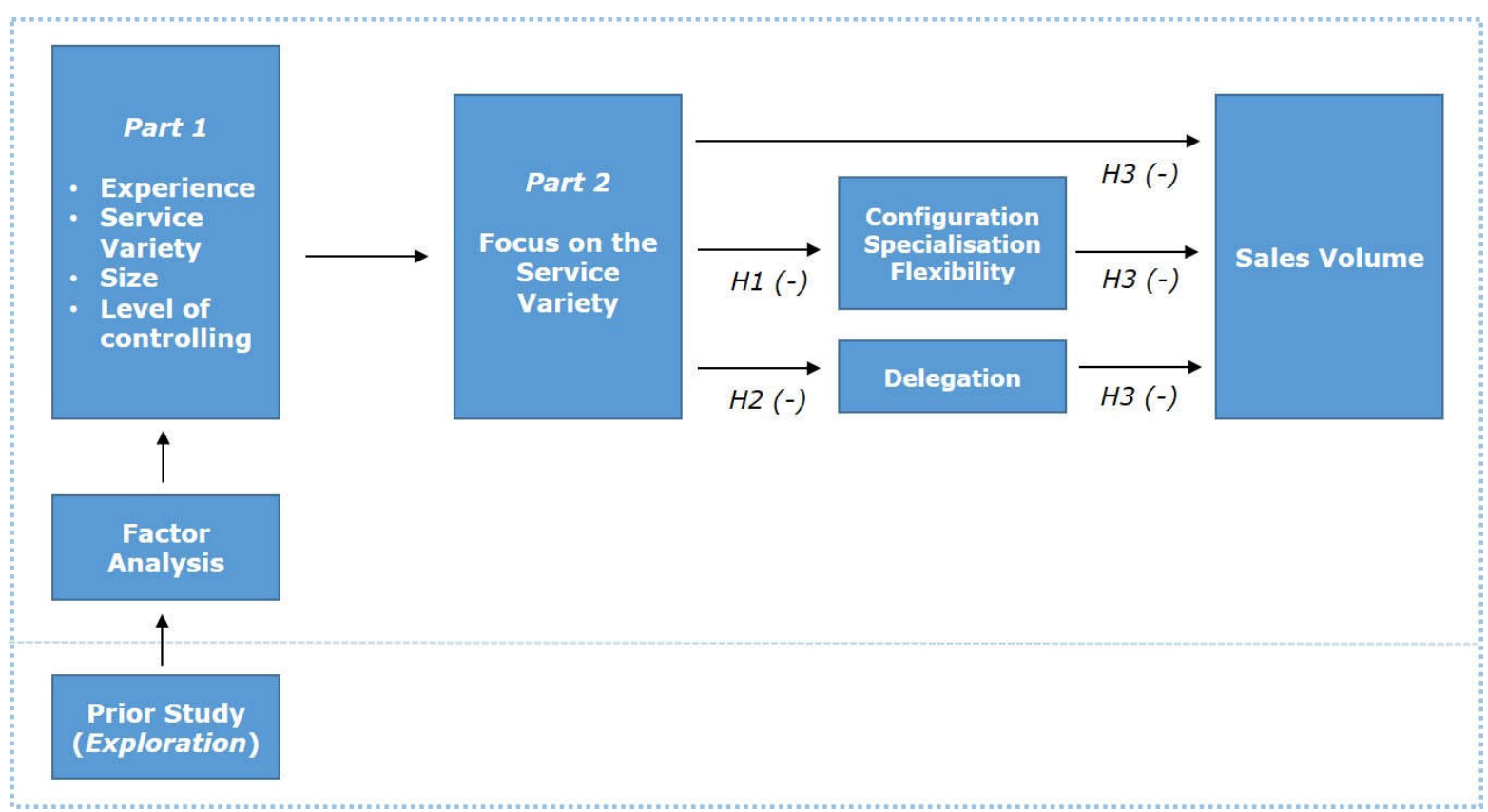

Figure 2 - Setting the hypothesis in the research procedure

Part 1: In accordance with Figure 1, we first analyse the situational parameters, trying to sort out relevant characteristics in GRH. For further approaches we intend to reduce the data set because the structure of a set of variables can then be better understood and the problem with multicollinearity can be avoided. In a previous pilot study, we exploratory determined 64 different characteristics on $\mathrm{GRH}$. On this account, a confirmatory factor analysis (IBM SPSS 23/24) was embedded, conducted on these items. Principally, there are now factors including a set of single variables. The choice of contingent variables was deductively sorted, due to the fact that it is not clear at this stage if the rotation will be successful in finding homogeneous factor groups. After the run, the reliability of the scale is post-analysed with Cronbach's $\alpha$. This is important to validate the questionnaire.

Part 2: We start running the correlation and regression procedure to find feasible interrelationship between the service variety and structural variables $(\mathrm{H} 1)$ as factors and the level of delegation $(\mathrm{H} 2)$. The relationship between these variables aims to exemplify the architecture (the 'fit'). The impact on the economic parameter is tested according to hypothesis 3 . All procedures were run in one direction (dependent/independent variables), trying to explain causality.

The choice of the right regression model depended on the level of measurement (Buchanan \& Bryman, 2009), because of different response options and parameters. Along with the correlation, we performed multiple regressions on the structural variables, ordinal regression on the economic variables, and multinomial, logistic regression on delegation and on economic variables. With these new insights, the hypotheses will be answered. All data were illustrated with Microsoft Excel 2013. 
The questionnaire consists of 29 questions in 3 sections: 1) General information about the company and owner/CEO (including occupation and product portfolio); 2) formal, structural organization (e.g., configuration, specialisation, departmentalization and flexibility); and 3) process organization (e.g., centralisation, delegation and control). At the end of the questionnaire, the sales volume was requested. With regard to the two main objectives of the research, identifying characteristics and interrelationship between situation, structure and economy, it is important to find the right level of measurement for the structural variables, following Kieser \& Kubicek (1995). Thus, consistent scales were chosen to describe the structural organization: Predominantly ordinal variables in all three sections of the questionnaire principally followed in the same order on a five-point Likert scale, ranging from 1 (least) to 5 (most). There were also nominal variables (service portfolio), binary variables (departmentalization) and continuous variables (number of staff). Some discrete variables were treated as continuous variables, predominantly the organizational structure section. Though some questions were formulated in a different direction, these were later adjusted when transforming into IBM SPSS 23/24.

Descriptive statistics:

The survey participants were predominantly owners $(83 \% ; N=280)$, indicating a majority of private companies, with an average age of 51 years $(N=279)$. The companies were mostly founded between 61 and 100 years ago, $(32.2 \% ; N=276)$. Successor establishments were not arranged $(43.8 \% ; N=240)$, though $13.4 \%$ were planning to close in the future $(N=240)$. With a high degree of unarranged successor establishment, future prospects are significantly not positive. Of the respondents, $57.24 \%(N=283)$ do crop production, and $71 \%(N=283)$ are in retail distribution. The companies are mainly situated in towns of $5,000-20,000$ inhabitants $(31.9 \% ; N=276)$-which are considered small towns, following the generally accepted declaration in Europe (Gabler, 2014) -with a catchment area of $10-20 \mathrm{~km}^{2}(42.6 \% ; N=270)$. The catchment area may indicate, for example, the spending power of the customer, and increases with increasing product variety (Spectrum.de, 2016). With an area of $10-20 \mathrm{~km}^{2}$, it seems that more than circumjacent customers visit.

Operational performances: Of the owners / CEOs, 33.9\% $(N=218)$ rate themselves as practitioners, performing the day-to-day tasks of $56.3 \%(N=220)$. Service experience is less than 30 years $(56.1 \%, N=205)$, operational emphasis is $75 \%-100 \%$ retail $(55.3 \%$, $N=221)$. Employment includes $6-10$ staff $(35.7 \%, N=210)$, sales volume in euros is $350,000-600,000(29.1 \%, N=213)$, and the number of present pure services is 11 $(N=283)$ out a total of 34 . The controlling variables differ only slightly, moderately on a medium level (all $N_{s}=283$ ). There are only a small number of independent service departments $(8.8 \%, N=283)$ and ancillary departments $(4.6 \%, N=283)$. The staff works moderately in different departments on a medium level (flexibility) with $42.2 \%, N=271$. The average number in the hierarchy is $3.37(N=283)$, which is fairly even. The average span of control is $2.4(N=283)$; that is, only a few employees per supervisor which indicates either few staff or many superiors. The average hierarchy configuration is $1.39(\mathrm{~N}=283)$, which means relatively few staff in the hierarchy. The average control intensity of 0.32 $(N=283)$ is equivalent to the span of control. The participating companies are scattered throughout Germany with different sizes and locations of towns/regions. There is a normal distribution of postcodes with $N=260$.

\section{RESULTS OF STUDY}

The conventions of contingency approaches are based on contextual, individual situations. In contrast to previous studies, which mainly focussed on the manufacturing industry sector, this paper examines German retail horticulture, which is characterized by strongly heterogeneous structures, as identified in a previous pilot study (Engelke, 2016). On this basis, a confirmatory factor analysis was first conducted on 64 items with Varimax rotation. The Kaiser-Meyer-Olkin (KMO) measure verified the sampling adequacy for the analysis, where KMO $=0.761$ ('middling', according to Moutinho \& Hutcheson, 1999) and all $\mathrm{KMO}$ values for individual items were greater than 0.65 , which is well above the 
acceptable limit of 0.5 (Field, 2014). An initial analysis was run to obtain eigenvalues for each factor in the data. Four factors had eigenvalues over Kaiser's criterion of 1 and in combination explained $39.15 \%$ of the variance. The items that cluster on the same factors suggest that factor 1 represents the level of controlling, factor 2 represents size, factor 3 represents service variety and factor 4 represents experience. As Table 1 shows, these four factors include a set of single variables.

As a test of the reliability of the scales, level of controlling, size and service variety all had high reliabilities with Cronbach's $\alpha=0.85 / 0.86$. Experience had relatively low reliability with Cronbach's $\alpha=0.68$.

Interrelation between situation and structure:

Table 1 - Situational variables and factors correlating on structural variables (Spearman's correlation coefficient)

\begin{tabular}{|c|c|c|c|c|c|c|c|c|}
\hline Factor 1-4 & $\begin{array}{l}\text { Includes Situational } \\
\text { Variables }\end{array}$ & $\begin{array}{l}\text { Number } \\
\text { Departments }\end{array}$ & $\begin{array}{l}\text { Number } \\
\text { Ancillary }\end{array}$ & Flexibility & $\begin{array}{l}\text { Number } \\
\text { Hierarchy }\end{array}$ & $\begin{array}{l}\text { Hierarchy } \\
\text { Configuration }\end{array}$ & $\begin{array}{l}\text { Span of } \\
\text { Control }\end{array}$ & $\begin{array}{l}\text { Control } \\
\text { Intensity }\end{array}$ \\
\hline Experience & $\begin{array}{l}\text { Foundation } \\
\text { Experience }\end{array}$ & $\begin{array}{l}0.024 \\
-0.013\end{array}$ & $\begin{array}{l}-0.016 \\
-0.134\end{array}$ & $\begin{array}{l}-0.081 \\
0.017\end{array}$ & $\begin{array}{l}-0.079 \\
0.007\end{array}$ & $\begin{array}{l}-0.062 \\
-0.044\end{array}$ & $\begin{array}{l}-0.039 \\
0.074\end{array}$ & $\begin{array}{l}-0.011 \\
0.013\end{array}$ \\
\hline \multirow{7}{*}{ Size } & \multirow{2}{*}{$\begin{array}{l}\text { No. operational } \\
\text { manager departments } \\
\text { No. } \\
\text { manager (retail) }\end{array}$} & 0.024 & 0.000 & 0.014 & 0.124 & 0.080 & -0.015 & $0.214^{*}$ \\
\hline & & 0.111 & 0.054 & -0.133 & 0.176 & $0.279^{* *}$ & $0.216^{*}$ & $0.222^{*}$ \\
\hline & $\begin{array}{l}\text { No. departments } \\
\text { manager (service) }\end{array}$ & 0.084 & 0.094 & -0.076 & 0.006 & $0.256^{*}$ & 0.059 & 0.137 \\
\hline & No. worker (service) & 0.081 & -0.019 & -0.061 & 0.077 & 0.080 & 0.078 & 0.052 \\
\hline & No. office worker & 0.124 & -0.005 & 0.020 & 0.123 & 0.118 & 0.096 & 0.171 \\
\hline & No. apprentices & 0.058 & 0.125 & -0.042 & 0.151 & 0.016 & 0.114 & 0.082 \\
\hline & Total no. staff & 0.081 & -0.010 & -0.095 & 0.131 & 0.086 & 0.120 & $0.158^{*}$ \\
\hline \multirow{7}{*}{$\begin{array}{l}\text { Level of } \\
\text { Controlling }\end{array}$} & Strategy planning & 0.071 & 0.061 & 0.085 & 0.073 & -0.034 & -0.060 & 0.048 \\
\hline & Budget planning & 0.061 & 0.117 & 0.024 & 0.056 & -0.010 & -0.030 & 0.071 \\
\hline & Earning/Expenditure & 0.090 & 0.000 & $-0.0<0$ & 0.170 & $-0.0<0$ & -0.004 & 0.109 \\
\hline & planning & 0.068 & 0.091 & 0.021 & 0.058 & -0.043 & -0.082 & 0.037 \\
\hline & Capital planning & 0.009 & 0.030 & -0.040 & 0.014 & -0.034 & -0.090 & 0.067 \\
\hline & Statistics & 0.071 & $0.148^{*}$ & -0.027 & 0.102 & -0.001 & -0.053 & 0.013 \\
\hline & Post calculation & 0.031 & -0.006 & -0.017 & -0.006 & -0.077 & -0.081 & 0.076 \\
\hline \multirow{2}{*}{$\begin{array}{l}\text { Service } \\
\text { Variety }\end{array}$} & No. core performances & $0.179^{\star *}$ & $0.164^{\star *}$ & -0.029 & $0.557^{\star *}$ & $0.400^{\star *}$ & $0.479^{* *}$ & $0.385^{\star *}$ \\
\hline & No. hybrid services & 0.067 & 0.041 & -0.050 & $0.419^{* *}$ & $0.287^{* *}$ & $0.372^{* *}$ & $0.342^{* *}$ \\
\hline
\end{tabular}

Notes: Only those single variables with high eigenvalues are listed, after factor rotation. ${ }^{*} p<0.05$ (2-tail), ${ }^{* *} p<0.01$ (2-tail).

In the left column, you see factors 1-4 and the embedded single contingent. The data are visualized with a heatmap. Changing colours means increasing values. Firstly, significant relationships between situation and structure are mainly on the service variety $(p<0.01)$. Secondly, the largest effects are with the number of hierarchy, related to the following factors: service variety $(r s=0.557)$, span of control ( $r s=0.479$ ), hierarchy configuration ( $r s=0.400$ ) and control intensity ( $r s=0.385)$, all with $p s<0.01$. It is clear that service variety has the highest impact on organizational structure, which was unexpected; normally, following Wernitz (2015), size is the major factor in many studies. Size is also of relevance, but it is on a minor level of significance. Both single variables of the factor service variety show similar results. Differences are solely in the level of shape: Core performances show higher values, which could explain higher organizational structures; meanwhile hybrid services don't affect the structures so much-they are part of the product.

Next, we start running multiple regression in order to find predictabilities on this result.

As the model shows, service variety is the main predictor on most of the dependent structural variables. The relevant structure variables, explaining fair model stability and acceptable variances (Chin, 1998), are solely configuration variables: number of hierarchy $\left(R^{2}=0.196\right)$, span of control $\left(R^{2}=0.113\right)$ and hierarchy configuration $\left(R^{2}=0.101\right)$, all ps $<0.000$.

The increasing simultaneous span of control and number of hierarchy is a surprise, for they are usually an opposed ratio (Keren \& Levhari, 1979). A disproportionate rise in the number of staff, which indicates the size, could explain the ratio's outcome. This finding concurs with an increasing hierarchy configuration, which also indicates that the number of 
staff could be the responsible factor. To sum up: The more service variety, the more staff, and the more hierarchy, the higher the span of control and hierarchy configuration.

Table 2 - Multiple regression: Linear model of predictor of different structural variables (var.)

\begin{tabular}{|c|c|c|c|c|c|}
\hline \multicolumn{6}{|c|}{ Coefficient: Number of Hierarchy } \\
\hline \multirow{3}{*}{1} & (Constant) & 3.371 & 0.082 & & $P=0.000$ \\
\hline & Factor Service Variety & 0.628 & 0.082 & 0.417 & $P=0.000$ \\
\hline & (Constant) & 3.371 & 0.080 & & $P=0.000$ \\
\hline \multirow[t]{2}{*}{2} & Factor Service Variety & 0.628 & 0.080 & 0.417 & $P=0.000$ \\
\hline & Factor Size & 0.253 & 0.080 & 0.168 & $P=0.002$ \\
\hline \multirow{2}{*}{\multicolumn{6}{|c|}{$\begin{array}{l}\text { Notes: a) Dependent var.: Number of Hierarchy; b) } R^{2}=.171 \text { for Step } 1 ; \Delta R^{2}=.196 \text { for Step } 2(p s<.000) \\
\text { Coefficient: Hierarchy Configuration }(H C)\end{array}$}} \\
\hline \multicolumn{5}{|c|}{ Coefficient: Hierarchy Configuration (HC) } & \\
\hline Step & & $\mathrm{b}$ & SE B & $\beta$ & $\mathrm{p}$ \\
\hline & (Constant) & 1.398 & 0.050 & & $P=0.000$ \\
\hline & Factor Service Variety & 0.285 & 0.050 & 0.323 & $P=0.000$ \\
\hline \multicolumn{6}{|c|}{ Notes: a) Dependent var.: Hierarchy Configuration; b) $\Delta R^{2}=0.101$ (ps $<0.000$ ) } \\
\hline \multicolumn{6}{|c|}{ Coefficient: Span of Control } \\
\hline Step & 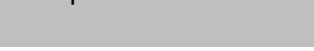 & $\mathrm{b}$ & SE B & $\beta$ & $\mathrm{p}$ \\
\hline \multirow{2}{*}{1} & (Constant) & 2.402 & 0.102 & & $P=0.000$ \\
\hline & Factor Service Variety & 0.622 & 0.102 & 0.341 & $P=0.000$ \\
\hline
\end{tabular}

Notes: 95\% bias-corrected and accelerated confidence intervals. Confidence intervals and standard errors based on 283 bootstrap samples. Only significant results are pictured.

a) Dependent var.: Span of Control; b) $\Delta R^{2}=0.113$ (ps $<0.000$ )

To check the results, the regression was also run with single variables (instead of factors), showing the same result. Flexibility, the number of service departments and ancillary departments are all minor, which means that departmentalization has no significant impact in this approach, in contrast to findings by Lay (2009) and Rainfurth (2003). On this account, the impact of services could play a vital role. These findings reject the first hypothesis.

Interrelation between situation and delegation. The questions for the delegation variables were asked with a nominal scale that had 3 options (owner/CEO, employee, office). For this reason, a multinomial logistic regression model was chosen to find out which people participated in different process tasks. These were tested against the four situational factors.

The pseudo- $R^{2}$ values (Cox \& Snell and Nagelkerke) are all $>0.0$, which means that if the predictor variables increase, the likelihood of the outcome variables does as well. The odds ratio (exponential of $\mathrm{B}$ ), as the main coefficient of determination in logistic regression, shows that most variables have a negative effect on the outcome and that predominantly size (and also experience) show values greater than 1 . This result means that if the predictor increases, the odds of the outcome also increase, and in a higher proportion, as well (Field, 2014). When size increases, delegation also increases. The service variety and the level of controlling are minor. To illustrate: When the size is increased by 1 unit, the proposal management with the owner/CEO decreases by 0.576 units, which is poor. When these tasks are delegated on the office, the values will increase by 1.631 units, meaning that the level of delegation is of significant importance.

The results also show that the influence of the owner/CEO is of major significance regarding the ratio of variables, which is in accordance with Weiand (2009); Kraus, Harms \& Schwarz (2007). Given the fact that the number of tasks differs between the factor variables (the size is most important, level of controlling is least important, as measured by the odds ratio), meaning that some variables show positive impact on the delegation, the second hypothesis will be also be rejected. 


\begin{tabular}{|c|c|c|c|c|c|}
\hline $\begin{array}{l}95 \% \mathrm{Cl} \text { for Odds Ratio } \\
\text { Outcome Variables (delegation) }\end{array}$ & Predictor Variables & b (SE) & Lower & Odds Ratio & Upper \\
\hline Proposal Management (Owner/CEO) ${ }^{1}$ & Size & $-0.552(0.183)$ & 0.402 & 0.576 & 0.824 \\
\hline Proposal Management (Office) ${ }^{2}$ & Size & $0.489(0.252)$ & 0.996 & 1.631 & 2.670 \\
\hline Acquisition / Marketing (Owner/CEO) ${ }^{3}$ & Size & $-0.771(0.202)$ & 0.311 & 0.462 & 0.687 \\
\hline Acquisition / Marketing (Owner/CEO) ${ }^{4}$ & Service Variety & $-0.423(0.208)$ & 0.436 & 0.655 & 0.986 \\
\hline Acquisition / Marketing (Office) ${ }^{5}$ & Service Variety & $-0.776(0.357)$ & 0.231 & 0.465 & 0.936 \\
\hline Operational Perform. (Owner/CEO) ${ }^{6}$ & Service Variety & $-1.189(0.530)$ & 0.108 & 0.305 & 0.861 \\
\hline Operational Perform. (Owner/CEO + Employee) ${ }^{7}$ & Level of controlling & $-0.756(0.304)$ & 0.259 & 0.470 & 0.851 \\
\hline Accounting (Owner/CEO) ${ }^{8}$ & Size & $-0.813(0.217)$ & 0.290 & 0.443 & 0.679 \\
\hline Customer Service (Owner/CEO) ${ }^{y}$ & Size & $-0.736(0.232)$ & 0.304 & 0.479 & 0.755 \\
\hline Customer Service (Employee) ${ }^{10}$ & Experience & $-0.765(0.308)$ & 0.255 & 0.465 & 0.850 \\
\hline Customer Service (Owner/CEO + Employee) ${ }^{11}$ & Size & $-0.390(0.196)$ & 0.461 & 0.677 & 0.995 \\
\hline Purchasing (Owner/CEO) ${ }^{12}$ & Experience & $-0.516(0.247)$ & 0.368 & 0.597 & 0.968 \\
\hline Purchasing (Employee) ${ }^{13}$ & Size & $0.519(0.264)$ & 1.003 & 1.681 & 2.818 \\
\hline Purchasing (Employee) ${ }^{14}$ & Experience & $-0.993(0.313)$ & 0.201 & 0.371 & 0.684 \\
\hline Purchasing (Owner/CEO + Employee) ${ }^{15}$ & Experience & $-0.673(0.245)$ & 0.315 & 0.510 & 0.825 \\
\hline Work Organization (Owner/CEO) & Size & $-0.698(0.263)$ & 0.297 & 0.498 & 0.833 \\
\hline Work Organization (Owner/CEO) ${ }^{17}$ & Experience & $-0.599(0.271)$ & 0.323 & 0.549 & 0.935 \\
\hline Accountancy (Office) ${ }^{18}$ & Experience & $0.362(0.186)$ & 0.997 & 1.436 & 2.068 \\
\hline Accountancy (Owner/CEO) ${ }^{19}$ & Size & $-1.021(0.242)$ & 0.224 & 0.360 & 0.579 \\
\hline
\end{tabular}

Notes:

95\% bias-corrected and accelerated confidence intervals.

Confidence intervals and standard errors based on 283 bootstrap samples. Only significant results are pictured.

${ }^{1} R^{2}=.157$ (Cox \& Snell), 0.180 (Nagelkerke). Model $X^{2}(4)=23,585, p<0.001$;

${ }^{2} R^{2}=0.157 / 0.180$. Model $X^{2}(4)=23,585, p<0.001 ;{ }^{3} R^{2}=0.164 / 0.191$. Model $X^{2}(4)=18,787, p<0.001$;

${ }^{4} R^{2}=0.164 / 0.191$. Model $X^{2}(4)=18,787, p<0.001 ;{ }^{5} R^{2}=0.164 / 0.191$. Model $X^{2}(4)=18,787, p<0.001$;

${ }^{6} R^{2}=0.199 / 0.226$. Model $X^{2}(3)=11,003, p<0.05 ;{ }^{7} R^{2}=0.199 / 0.226$. Model $X^{2}(3)=10,803, p<0.05$;

${ }^{8} R^{2}=0.209 / 0.230$. Model $X^{2}(4)=36,847, p<0.001 ;{ }^{9} R^{2}=0.166 / 0.179$. Model $X^{2}(4)=15,805, p<0.005$;

${ }^{10} R^{2}=0.166 / 0.179$. Model $X^{2}(4)=15,517, p<0.005 ;{ }^{11} R^{2}=0.166 / 0.179$. Model $X^{2}(4)=15,805, p<0.005$;

${ }^{12} R^{2}=0.145 / 0.158$. Model $X^{2}(4)=15,825, p<0.05 ;{ }^{13} R^{2}=0.145 / 0.158$. Model $X^{2}(4)=17,420, p<0.005$;

${ }^{14} R^{2}=0.145 / 0.158$. Model $X^{2}(4)=13,359, p<0.05 ;{ }^{15} R^{2}=0.145 / 0.158$. Model $X^{2}(4)=13,359, p<0.05$;

${ }_{16}^{16} R^{2}=0.189 / 0.214$. Model $X^{2}(4)=24,584, p<0.001 ;{ }_{17}^{17} R^{2}=0.189 / 0.214$. Model $X^{2}(4)=9,509, p<0.050$;

${ }^{18} R^{2}=0.276 / 0.314$. Model $X^{2}(4)=16,541, p<0.001 ;{ }^{19} R^{2}=0.276 / 0.314$. Model $X^{2}(3)=49,582, p<0.001$.

Interrelation between situation and sales volume. The questions for the economic variables were asked with a nominal scale that had 6 options (where $1=<100,000$, and $6=>1,500,000 €$ ). These questions were to discover the impact of the context factors on different levels of sales volume. For this reason, a multinomial, logistic regression model was chosen again.

Table 4 - Multinomial logistic regression: Linear model of predictor on sales volume

\begin{tabular}{|llllll|}
\hline $\begin{array}{l}95 \% \mathrm{Cl} \text { for Odds Ratio } \\
\text { Outcome Variables in } €\end{array}$ & Predictor Variables & $\mathrm{b}(\mathrm{SE})$ & Lower & $\begin{array}{l}\text { Odds } \\
\text { Ratio }\end{array}$ & Upper \\
\hline $100,000-200,000$ & Experience & $-1.181(0.551)$ & 0.104 & 0.307 & 0.904 \\
$100,000-200,000$ & Size + Experience & $-0.942(0.471)$ & 0.155 & 0.390 & 0.981 \\
$200,000-350,000$ & Size & $1,739(0.533)$ & 2.003 & 5.692 & 16.177 \\
$200,000-350,000$ & Experience & $-1.062(0.472)$ & 0.137 & 0.346 & 0.871 \\
$350,000-600,000$ & Level of controlling & $0.979(0.337)$ & 1.374 & 2.661 & 5.153 \\
$350,000-600,000$ & Size & $2.073(0.545)$ & 2.733 & 7.951 & 23.132 \\
$350,000-600,000$ & Experience & $-1.467(0.479)$ & 0.090 & 0.231 & 0.590 \\
$350,000-600,000$ & Size + Experience & $-0.945(0.350)$ & 0.196 & 0.389 & 0.772 \\
$600,000-1,500,000$ & Level of controlling & $1.480(0.364)$ & 2.154 & 4.393 & 8.959 \\
$600,000-1,500,000$ & Size & $3.191(0.591)$ & 7.642 & 24.321 & 77.407 \\
$600,000-1,500,000$ & Experience & $-1.463(0.490)$ & 0.089 & 0.231 & 0.604 \\
$600,000-1,500,000$ & Size + Experience & $-0.947(0.312)$ & 0.210 & 0.388 & 0.716 \\
$>1,500,000 €$ & Level of controlling & $1.932(0.464)$ & 2.778 & 6.901 & 17.145 \\
$>1,500,000 €$ & Size & $4.681(0.687)$ & 28.081 & 107.878 & 414.430 \\
$>1,500,000 €$ & Size + Experience & $-1.662(0.393)$ & 0.088 & 0.190 & 0.410 \\
\hline
\end{tabular}

95\% bias-corrected and accelerated confidence intervals. Confidence intervals and standard errors based on 283 bootstrap samples. Only significant results are pictured. The reference-category is $<100,000 €$

Factor Level of controlling: $R^{2}=0.515$ (Cox \& Snell), 10.535 (Nagelkerke). Model $X^{2}(5)=39,095, p<0.001$

Factor Experience: $R^{2}=0.515 / 0.535$. Model $X^{2}(5)=17,963, p<0.005$;

Factor Size: $R^{2}=0.515 / 0.535$. Model $X^{2}(5)=114,193, p<0.001$

Factor Size + Experience: $R^{2}=0.515 / 0.535$. Model $X^{2}(5)=27,772, p<0.005$

Table 4 shows the ascending sales volume variables (first column) and the predictor variables (second column) with significant values. Predictors on sales volume are size, level of controlling, experience and the interaction of size + experience. We found different 
values within the various sales levels. The pseudo- $R^{2}$ values (Cox \& Snell and Nagelkerke) are all high values above $>0.0$, which means that if the predictor variables increase, the likelihood of the outcome variables does very well. The Odds ratio (exponential of B), as the main coefficient of determination in logistic regression, shows that the size and the level of controlling have predominantly high values $>1$, which means that if the predictor increases, the odds of the outcome increases, as well (Field, 2014): By example of the sales volume: The higher the sales volume, the higher the odds ratio, and therefore the higher the likelihood of the size and level of controlling factors. The sales volume significantly increases with increasing size $\left(r_{s}=0.540, p<0.01\right)$. More staff correlates with more sales volume, which is in accordance with the literature (e.g. Furnham \& Fudge, 2015). Increasing sales volumes with increasing levels of controlling $\left(r_{s}=0.316, p<0.01\right)$ could be explained with growing size. To find relationships between these both factors is not possible, because of significant interspaces in the factor rotation which enable a clear separation (Mak \& Nebebe, 2016). Instead, we run the correlation with single variables and found medium effects $(p<0.01)$ which means that size and level of controlling are related and could indicate interactive effects.

For example, in the category $350,000-600,000 €$, when size is increased by 1 unit, the sales volumes increases by 7.951 units (respectively 2.661 with the level of controlling). This means, that size (number of staff) and level of controlling are significantly associated with sales volumes. In contrast, experience shows low odds ratios below $<1$, which means that there are decreasing values with increasing sales volumes. It can be concluded that only the unexperienced companies have rising sales, which could lead to the conclusion that there are young companies or new services in the portfolio with no experience. This effect will be reinforced with the interaction of size and experience, when the size, as a main variable with high odds ratios, has single values of 7.951 but only 0.389 in interaction. So, there is a negative, contrary effect of experience.

Interrelation between structure and sales volume. Running different regression models, such as logistic and ordinal regression, which can be applied for the six ascending sales volume levels, we found no significant connection, for there are low coefficients and $R^{2}$. Service variety as a factor had no influence on the structure variables. To verify, we tried the regression with the single variable 'current core services', finding the same result. To find an explanation, we use the example of the span of control: Components are the total number of staff and superiors, which is in turn part of the size. Regarding the unambiguous influence of size on the sales volume (see Table 4), we conclude an interaction of size and service variety. There has to be a conflict, either within the single components or between the factors as a whole. These interactions of multiple factors seem to be the cause for the negative effect on the sales volume. However, the configuration as a component of the structure has no impact on the sales volumes.

Interrelation between delegation and sales volume. The single tasks of delegation are run into ordinal regression with the sales volume, as Table 5 shows.

The $R^{2}$-values (Cox \& Snell/ Nagelkerke) all have high values $\left(R^{2}=0.599 / 0.624\right.$, $p=<0.001$ ), which provides a good explanation of the variance and accordingly the model. If the predictor variables increase, the likelihood of the outcome variables does very well. All B-values show a negative coefficient of determination with predominantly low values $<1$, which means negative effects on the outcome variables. Variables that influence sales volumes are acquisition/marketing (office), operational performances (owner/CEO + employee), work organization (owner/CEO), statistics (owner/CEO), planning (office), consulting (in person).

To illustrate with operational performances: Increasing the sales volumes by 1 unit decreases operational performances with the owner/CEO by 3.66 units $(p<0.001)$. This means, that the owner/CEO should reduce the day-to-day tasks when a certain sales volume (and correspondingly the size) is achieved.

Table 5 - Ordinal regression: Linear model of delegation (predictor) on sales volume (outcome) 
Sales Volume vs. Acquisition/Marketing: Office

Sales Volume vs. Operational Performances:

Owner/CEO + Employee

Sales Volume vs. Work Organization: Owner/CEO

Sales Volume vs. Statistics: Owner/CEO

Sales Volume vs. Planning: Office

Sales Volume vs. Consulting: In Person

$\begin{array}{lll}-3.658(1.267) & -6.141 & -1.174 \\ -1.808(0.920) & -3.612 & -0.004 \\ -1.062(0.472) & 0.479 & 4.418 \\ -1.870(0.729) & -3.299 & -0.440 \\ -5.526(2.819) & -11.052 & -0.001 \\ -1.794(0.918) & -3.592 & 0.005\end{array}$

Notes:

95\% bias-corrected and accelerated confidence intervals. Confidence intervals and standard errors based on 283

bootstrap samples. Only significant results are pictured.

$R^{2}=0.599$ (Cox \& Snell) /0.624 (Nagelkerke). Model X' (45) = 97,643, $p<0.001$

These tasks have to be delegated to staff, which is in accordance with Titscher, Meyer \& Mayrhofer (2008) and Lentz (2004), as a sign of a higher level of delegation when the company is growing. Summarizing, the structure has no significant impact on sales volumes, and there is accordingly no coordinated interaction of situational, structure and delegation variables. Thus, we support the third hypothesis. Figure 3 shows a summary of the results.

Building the model:

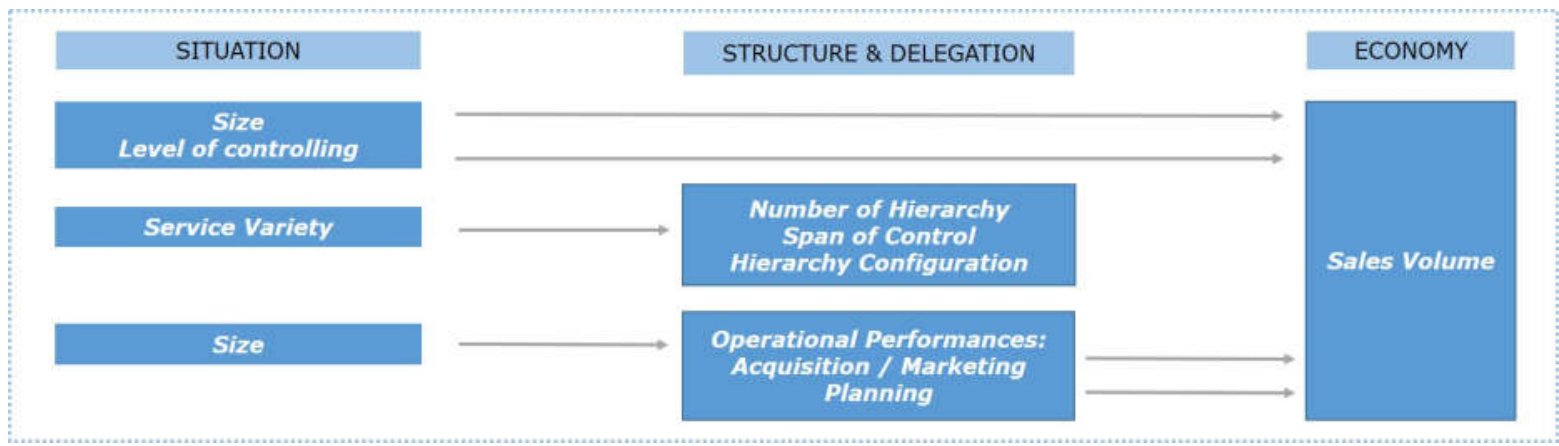

Figure 3 - Model of associated parameters of situation, structure and economy.

Based on the regression procedures; only significant results pictured.

The causal relationship between the parameters are shown with arrows: the a) the size and the level of controlling with sales volume, b) service variety with span of control, hierarchy configuration and number of hierarchy, c) size with acquisition and planning (operational performances), d) acquisition and planning (operational performances) with sales volume.

\section{DISCUSSION OF RESULTS}

In a two-step approach, this paper first aims to systematise relevant, internal characteristics, building on previous research. Second, we try to emerge the impact of the service variety on the organizational structure and economic parameters in order to find the right combination for $\mathrm{GRH}$.

Part 1: Identifying significant characteristics. Previous studies on GRH predominantly describe single topics, such as characteristics (e.g., BMELV, 2013; Bahnmüller \& Hintze, 2003), success factors (Schwarz, 2008), customer satisfaction (Schöps, 2013), risk management (Von Allwörden, 2005), assortment (Menrad, 2008), controlling application (Gabriel \& Bitsch, 2016; Lentz, 2008), statistics (Dirksmeyer \& Fluck, 2013) and intercompany comparison (ZBG, 2015). But there is still, to the authors' knowledge, a gap in research for the interaction of context, structure and economic parameters with services. Choosing the CA as the appropriate method, we systematically found 64 different characteristics in a quantitative way, gathered from an online survey and previous exploration. Therefrom, four contingency factors were found to be significant: size, level of controlling, experience and service variety as internal parameters. These homogeneous groups all have $\mathrm{KMO}$ values for individual items greater than 0.65 , which is well above the acceptable limit of 0.5 (Field, 2014). Cronbach's a confirms the reliability of this categorising 
with $\alpha=0.85 / 0.86$ respectively and $\alpha=.68$ with the experience factor variable, which is not on safe ground. The relevant literature subdivides internal and external variables (Vahs, 2009), so we restricted to the internal parameters; external parameters such as customer influence, central services characteristics, environmental and competition variables were not considered. With these first results given, we successfully dissolved the heterogeneity with finding homogeneous factors of $\mathrm{GRH}$, which encouraged finding interrelation on the structural parameters in the next step.

Part 2: Impact of the service variety on organizational structure. Concentrating on these four factors, we revealed different effects on the organizational structure. We found a large positive association between the factor of service variety and certain configurational variables, specifically the number of hierarchy $\left(r_{s}=0.557\right)$ and the span of control $\left(r_{s}=0.479\right)$, all $p_{s}$ [2-tail] $<0.01$; these results were backed by $R^{2}=0.196 / 0.113$, all $\mathrm{p}_{\mathrm{s}}<0.000$ in multiple regression, confirming acceptable validity of the model.

Returning to the research aims, we tried to analyse organizational structures with the assumption that services play a major role on GRH. With the large correlation given, this can be surely supported, but is the amount of services the main indicator? Reflecting that there is an average spectrum of only 11 out of 34 pure services $(N=234)$, we also analysed the kind of service. We found an average 7 (out of 27) hybrid products in portfolios $(\mathrm{N}=175)$, which is low. Hybrid products mean that the physical product is linked with an added service (e.g., Guide, Jayaraman \& Linton, 2003). As we explained, companies often start providing services with hybrid product as a first step in business. When the demand for service grows, the organizational structures and configuration need to be adapted. This goes along with the current results, as the services significantly affect the number of hierarchy, the span of control and the hierarchy configuration. Here we conclude that the employment is the key for this phenomenon, because all three structural variables are dependent on it: while the span of control describes the ratio of the total number of staff and executives, the hierarchy configuration describes the ratio of the total number and the number of hierarchy level. These facts are getting important when realizing, that the services in general are predominantly dependent on the staff and less the physical product (Wan, Evers and Dresner, 2012; Kahn, 1995 e.g.). Realising that the services are becoming more prominent on $\mathrm{GRH}$, the current empiricism shows major topicality. On the other hand, we could not find significance in departmentalization, which was not affected. When services are not assigned to particular service departments, they must be executed in dayto-day business. This leads to the conclusion that the status quo of 'structural servicing' is solely on its way but not very well developed in the participating companies. This conclusion is confirmed with the low level of pure and hybrid services. A low level of pure services could also indicate a higher level of specialisation and functional differentiation (Speer \& Hughey, 1995), but that cannot be answered yet. On this account, the number of services is a restricted parameter to evaluate success, as the non-significant effect on sales volumes confirms. The insight of the low level of departmentalization also indicates functional structures in primary organization, contrary to earlier studies (Engelke, 2013). Categorizing by function focusses on the performances (e.g., purchasing, marketing), which are centrally structured, enabling quick decisions and coordination, which is generally positive (Duncan, 1979). But central structuring also concentrates responsibilities on the superior, which causes the problem of overloading (e.g., Covin \& Slevin, 1988). Of particular interest is that functional structuring characterizes restricted, homogeneous product portfolios in a stable environment (e.g., Voigt, 2016), in contrast to division structuring, which moreover characterizes larger enterprise sizes. This also corresponds with our results, for there is also a relatively low number of products, as we described earlier.

Trying to categorize the development of organization (Anand \& Daft, 2007) in GRH, we face the simple self-determination of the primary organization as a sign that GRH is situated in the first era of organization. With these arguments in mind, it can be stated that the organizational structures on GRH are not quite sophisticated, which confirms the specialist literature (e.g., Gabriel \& Bitsch, 2014). Possible reasons for this organizational resistance with services can be explained with limitations in ability, resources, staff and 
demarcation (Rainfurth, 2003). Summing up, we deductively reason that GRH is clumsy with changing processes, which is in line with SMEs in general (Hutzschenreuter, 2009).

With these arguments, it is possible to explain the negative coefficient of determination with predominantly low B-values $<1$. The owner/CEO works too much in a central position that is predominantly the performing and organizing the work and running statistics. This misuse of the owner/CEO negatively affects the sales volume; these tasks have to be delegated to employees. Meanwhile, other tasks like acquisition, marketing and planning must not be done by the office; this should be done by superiors. So, the results reveal the reality of structural delegation in GRH, which is in line with Böckelmann (2005). The delegation itself is mainly affected by the size of the organization, showing high values of odds ratios $>1$ : With increasing size, the better is the level of delegation.

Contributing to the enterprise size, we confirm, results in direct and strong, causal interrelation to increasing the sales volume $\left(r_{s}=0.540, p<0.01, X^{2}(5)=114,193, p<\right.$ 0.001), which is not surprising, as the few literatures in CA has highlighted this before on different lines of business. This means, the more staff, the more sales volume (e.g., Furnham \& Fudge, 2015; Chenhall, 2003). But we also found the level of controlling as a significant factor variable. This result is a surprise, because, to the authors knowledge, only few studies in literature have supported it. We cannot purely state that there is an interactive effect with size (employment), sales volumes and level of controlling, because the factor analysis showed large distances between the size and the level of controlling. So, there must be another explanation, which cannot be answered safely.

To help, we can embrace other central components of $\mathrm{GRH}$ : retail and crop production. As the descriptive statistics showed, both are significant in most participating companies. Structure and process differ from pure and added services in the portfolio, depending on the operational emphasis (Rogelio \& Kellenberg, 2003). With this given, the importance of the service controlling for purposes of monitoring and navigating becomes popular, especially with a heterogeneous portfolio (product mix) (Becker \& Rech, 2013 e.g.) or as a function to retain rational management (Meffert \& Bruhn, 2009). These arguments could be cause for the rising application of controlling tools, and thus a reason for the positive effect on the sales volume. Furthermore, this could explain the high standard, on the contrary of previous research (e.g., BMELV, 2013). On this assumption, our results reveal fresh knowledge.

The moderate impact of the experience factor corresponds with previous results (e.g., Hall, 1972) but gives no reason to overrate, because the Cronbach's value was weak $(\alpha=0.68)$, so the informative value is limited.

Because potential process and outcome variables are involved in services (e.g., Edvardsson, Gustafsson \& Roos, 2005), the behaviour of the organization members (staff and superiors) must also be considered. This goes along with the principles of the analytical model of the $\mathrm{CA}$, as we chose the conceptual framework.

This research has highlighted new aspects of the heterogeneous retail horticulture industry in Germany and opens the door for subsequent organizational analysis. Particularly, the effect of the service portfolio on organizational structure needs to be analysed in more detail, remembering that the service variety showed no effect on the sales volume. It is conceivable that other findings will occur with different portfolio combinations. With this understanding, a subdivision of the portfolio at variable times in company's life cycle seems of most interest to get detailed knowledge. With the current findings, we created the foundation.

\section{CONCLUSION}

We gave proof that relevant situational characteristics on German retail horticulture (GRH) include the size, level of controlling, experience and service variety as internal factor variables, showing high eigenvalues. We found causal relationships between the service variety and the number of hierarchy, span of control and hierarchy configuration. The size is also of significant importance but on a minor level. Size faces positive correlation on delegation, and the size and the level of controlling also have adequate impact on the sales volume. Meanwhile the configuration variables have no impact on the sales volume. This 
means that sales volume is related to the size and the level of controlling but independent of the configuration. Accordingly, there is no coordinated interaction of contingency, structure and delegation variables with impact on the sales volumes. Structural delegations on sales volume are significantly acquisition/ marketing and planning as operational performance-variables, which are mostly done by the owner/CEO himself. These tasks show negative coefficients, which lead to the proposal that with growing sales, the level of delegation has to be improved and these tasks must be transferred to employees. On this account, central structures focussing on performances, not products, and a low level of departmentalization together make up the ideal organizational structure for $\mathrm{GRH}$.

\section{REFERENCES}

1. Al-Wagdani, A.M. (2010), Beyond Weberian bureaucracy: Max Weber on bureaucracy and his critics, in: Journal of the social sciences: 38(3): 11-25.

2. Anand, N. \& Daft, R. L. (2007), What is the right organization design?. Organizational Dynamics, 34(4), 329-344.

3. Armbrecht, W. (1992): Methodische Erläuterungen: Der situative Ansatz als konzeptioneller Bezugsrahmen, in: Armbrecht (Publ.), Innerbetriebliche Public Relations, Grundlagen eines situativen Gestaltungskonzepts, Beiträge zur sozialwissenschaftlichen Forschung,21. VS Verlag für Sozialwissenschaften. Wiesbaden.

4. Bahnmüller, H. \& Hintze (2011), in: Gartenbauliche Betriebslehre, Produktionsgartenbau Dienstleistungsgartenbau, 6. Stuttgart.

5. Bahnmüller, H. \& Hintze, C. (2003), in: Gartenbauliche Betriebslehre, Produktionsgartenbau Dienstleistungsgartenbau, 5. Stuttgart.

6. Becker, W. \& Rech, S. (2013), Wertschöpfungsorientiertes Dienstleistungscontrolling, in: Controlling, 25(10), 515-521.

7. Böckelmann, S. (1995), Unternehmertypus und Organisationsstruktur, Dissertation, Aachen.

8. Buchanan, D. \& Bryman, A. (2009), Organizational research methods: The Sage handbook of organizational research methods, Sage. London.

9. Bundesministerium für Ernährung, Landwirtschaft und Verbraucherschutz (BMELV) (2013), Zukunftsstrategie Gartenbau Abschlussbericht zum Zukunftskongress Gartenbau am 11./12. September 2013 in Berlin (2013), in: http://www.bmel.de/SharedDocs/Downloads/Landwirtschaft/Pflanze/Gartenbau/Zukunft sstrategieGartenbauBerichtKongress2013.pdf?_blob=publicationFileBonn.

10. Chandler, G.N. and Hanks, S.H. (1994), Founder competence, the environment, and venture performance, in: Entrepreneurship: Theory and Practice, 18(3), 77-90.

11. Chenhall, R.H. (2003), Management control systems design within its organizational context: Findings from contingency-based research and directions for the future, in: Accounting, Organizations and Society, 28(2-3), 127-168.

12. Chervonnaya, O. (2003), Customer role and skill trajectories in services, in: International Journal of Service Industry Management, 14, 347-363.

13. Chin, W.W. (1998), The partial least squares approach to structural equation modelling, in: Marcoulides, G.A. (ed.): Modern Methods for Business Research. Mahwah, 295-336.

14. Choi, J., Nazareth, D.L. \& Jain, H.K. (2010), Implementing Service-Oriented Architecture in Organizations, in: Journal of Management Information Systems, (26)4, 253-286.

15. Covin, J.G. \& Slevin, D.P. (1988), The influence of organization structure on the utility of an entrepreneurial top management style, in: Journal of Management Studies. 25(3), 217-234.

16. Da-Cruz, P., Oberender \& Partner \& Schwegel, P. (2011): Die optimale Dienstleistungstiefe, Ein integrierter Ansatz dargestellt am Beispiel von Gesundheitsdienstleistungen, in: BFuP, 4(63), 390-406. 
17. Deimel, K. (2008), Stand der strategischen Planung in kleinen und mittleren Unternehmen (KMU) in der BRD, in: Zeitschrift für Planung \& Unternehmenssteuerung. 19, 281-298.

18. Dirksmeyer, W. \& Fluck, K. (2013), Wirtschaftliche Bedeutung des Gartenbausektors in Deutschland, in: Thünen Report 2, Braunschweig.

19. Duncan, R. (1979), What is the right organization structure?: Decision tree analysis provides the answer, in: Organizational Dynamics. 7(3), 59-80.

20. Dutta, D.M. (1991), Relevance of product mix research strategy in tourism marketing, in: Annals of tourism. 18, 496-536.

21. Edvardsson, B., Gustafsson, A. \& Roos, I. (2005), Service portraits in service research: A critical review, in: International Journal of Service Industry Management. 16(1), 107 121.

22. Engelke, C. (2016): Explorative Analyse heterogener Organisationsstrukturen am Beispiel des gärtnerischen Einzelhandels. In: Berichte über Landwirtschaft, Bonn.

23. Engelke, C. (2013), Anforderungen an Einzelhandelsgärtnereien aus betriebswirtschaftlicher Perspektive im Rahmen des Dienstleistungscontrollings, in: Thünen Report 22, Aktuelle Forschung in der Gartenbauökonomie, Tagungsband zum 1. Symposium für Ökonomie im Gartenbau am 27. November 2013 in der Paulinerkirche Göttingen, Braunschweig.

24. Field, A. (2014), Discovering statistics using IBM SPP-Statistics. 4. Sage. London.

25. Furnham, A. \& Fudge, C. (2015), The five factor model of personality and sales performance, in: Journal of Individual Differences, 29(1), 11-16.

26. Gabler; http://wirtschaftslexikon.gabler.de/Definition/stadt.html, 19.12.2014.

27. Gabriel, A. \& Bitsch, V. (2014), Konzeptentwicklung für eine Systemanalyse im gärtnerischen Einzelhandel auf Unternehmensebene, in: Schriften der Gesellschaft für Wirtschafts- und Sozialwissenschaften des Landbaues e.V., (Publ.), http://ageconsearch.umn.edu/bitstream/156245/2/Poster2-Gabriel-

Konzeptentwicklung_c.pdf.

28. Gabriel, A. \& Bitsch, V. (2016), Nachhaltigkeit im gärtnerischen Einzelhandel, TUM, 2. Symposium für Ökonomie im Gartenbau, 01.03.2016, Braunschweig.

29. Gann, D.M. and Salter, A.J. (2000), Firms: The construction of complex products and systems, in: Research Policy, 29(7-8), 955-972.

30. Guerrieri, P. \& Meliciani, V. (2005), Technology and international competitiveness: The interdependence between manufacturing and producer services, in: Structural Change and Economic Dynamics, 16(4), 489-502.

31. Guide, V.D.R., Jayaraman, V. \& Linton, J.D. (2003), Building contingency planning for closed-loop supply chains with product recovery, in: Journal of Operations Management, 21(3), 259-279.

32. Hahn, D. \& Taylor, B. (1990), in: Strategische Unternehmungsplanung, Stand und Entwicklungstendenzen, Heidelberg, 5, 611.

33. Hall, R.H. (1972), Organizations. Structure and process, Englewood Cliffs, N.J.

34. Hohengartner, B. \& Hohengartner, H. (2016), Im Blickpunkt: Dienstleistungen im Gartenbau, in: ZVG Gartenbau Report, 42(September 2016), 24-26.

35. Hutzschenreuter, J. (2009), Management control in small and medium-sized enterprises: Indirect control forms, control combinations and their effect on company performance, Gabler, Wiesbaden.

36. Jacobs, M.A. \& Swink, M. (2011), Product portfolio architectural complexity and operational performance: Incorporating the roles of learning and fixed assets. In: Journal of Operations Management, 29, 677-691.

37. Kahn, B.E. (1995): Consumer variety-seeking among goods and services, an integrative review, in: Journal of Retailing and Consumer Services, 2(3), 139-148.

38. Kellog, D.L., 1995, A framework for strategic service management, in: Journal of Operations Management, 13(4), 323-337.

39. Keren, M. \& Levhari, D. (1979), The Optimum Span of Control in a Pure Hierarchy, in: Management Science, 25(11), 1162-1172. 
40. Kieser, A. (1985): Wie rational kann man die Organisation einer Unternehmung gestalten? in: Die Unternehmung, 4(39), 367-378.

41. Kieser, A. (2006): Organisationstheorien, Volume 6. Kohlhammer. Stuttgart.

42. Kieser, A. \& Kubicek, H. (1995), Organisation. Volume 3. Walter De Gruyter. Berlin.

43. Kraus, S., Harms, R. \& Schwarz, J. (2007), Zur Relevanz der strategischen Planung für das Wachstum junger KMU, in: ZfM Zeitschrift für Management, 2(4), 392-394.

44. Kubicek, H. \& Wollnik, M. (1975), Zur Notwendigkeit empirischer Grundlagenforschung in der Organisationstheorie, in: Zeitschrift für Organisation, 44: 301-312.

45. Lay, G. (2009), Auswirkungen der Organisation und der Außenorientierung von Dienstleistungen auf Innovationen, Studien zum deutschen Innovationssystem, in: Expertenkommission Forschung und Innovation (EFI), Fraunhofer Institut System- und Innovationsforschung. Volume 14.

46. Lee, M. (1989): Contingency approach to strategies for service firms, in: Journal of Business Research,19, 291-301.

47. Lentz, W. (2004), Die Gartenbauökonomie im Spannungsfeld von Theorie und Praxis in: Gartenbau in einer sich wandelnden Welt“, Forschungsberichte zur Ökonomie im Gartenbau, http://www2.htw-dresden.de/ lentz/pdf/99storck.pdf, Hannover.

48. Lentz, W. (2008), Controlling- Grundlagen und Werkzeuge, in: http://www.zbg.unihannover.de/fileadmin/institut/zbg/pdf_downloads/Fachtagung/2008/Beitrag_Lentz.pdf am 31.10.2015.

49. Lovelock, C.H. (1983), Classifying services to gain strategic marketing insights, in: Journal of Marketing, 4, 9-20.

50. Mak, T. \& Nebebe, F. (2016), Factor analysis and methods of supplier selection, in: International Journal of Supply Chain Management, 1(1), 1-9.

51. Marhaeni, F.Z. \& Nugroho, H.B. (2015), The influence of the marketing mix (Product, price, promotion, place, process, entrepreneurs and physical evidence) to customer satisfaction and loyalty in buying shredded beef in Palu City, Indonesia, in: International Journal of Economic Research, 12(1), 205-217.

52. Mayring, P. (2010), Qualitative Inhaltsanalyse, in: Günter Mey (Publ.)- Handbuch Qualitative Forschung. VS Verlag für Sozialwissenschaft. Wiesbaden.

53. Meffert, H. \& Bruhn, M. (2009): Dienstleistungsmarketing, Grundlagen, Konzepte, Methoden, Volume 6. Gabler, Wiesbaden.

54. Menrad, K. (2008), Gibt es Unterschiede von Einzelhandelsgärtnereien, Gartencentern und Baumärkten?, in: Infodienst Hochschule Weihenstephan-Triesdorf, http://www.hswt.de/fgw/infodienst/2008/april/unternehmensfuehrung

55. Meyerding, S. (2016): Organization 2020: An empirical study of the current and future importance of organizational issues for horticultural companies and their perceived competence in Germany, in: Russian Journal of Agricultural, 3(51), 58-69.

56. Miller, D. (1982), Evolution and revolution: A quantum view of evolution and revolution, in: Journal of Management Studies, 19(2).

57. Moutinho, G.D. \& Hutcheson, N. (1999): The multivariate social scientist, Sage. London.

58. Nesheim, T. (1990), Service management and organizational design, in: Scandinavian Journal of Management, 6(3), 181-195.

59. Oi, W.Y. (1983), Heterogeneous firms and the organization of production, in: Economy Inquiry, 21(2), 147-171.

60. Pugh, D.S. \& Hickson, D.J. (1968), Eine dimensionale Analyse bürokratischer Strukturen, in: Mayntz, R., Bürokratische Organisation, Köln/Berlin, 82-93.

61. Pugh, D.S., Hickson, D.J. \& Hinings, C.R. (1969), An empirical taxonomy of structures of work organizations, in: Administrative Science Quarterly 14(115-126).

62. Rainfurth, C. (2003), Der Einfluss der Organisationsgestaltung produktbegleitender Dienstleistungen auf die Arbeitswelt der Dienstleistungsakteure [Elektronische Ressource]: am Beispiel von KMU des Maschinenbaus, Dissertation. Darmstadt.

63. Reymann, D. (2009), Wettbewerbsanalysen für kleine und mittlere Unternehmen (KMUs), Theoretische Grundlagen und praktische Anwendung am Beispiel gartenbaulicher Betriebe, Volume 1, Reymann, Geisenheim. 
64. Rogelio, O. \& Kellenberg, R. (2003), Managing the transition from products to services, in: International Journal of Service Industry Management, 14(2), 160-172.

65. Schreyögg, G. (2003): Organisation. Grundlagen moderner Organisationsgestaltung; mit Fallstudien, Gabler. Wiesbaden, 4(358 ff.).

66. Schwarz, U. (2008), Erfolgsfaktoren für den Dienstleistungssektor im Gartenbau, Eine theoretische und empirische Untersuchung, Dissertation, in: http://deposit.d-nb.de/cgibin/dokserv?idn=994129475\&dok_var=d1\&dok_ext=pdf\&filename=994129475.pdf., Dissertation, TU München.

67. Schöps, J. (2013), Kundenzufriedenheit in direkt absetzenden Einzelhandelsgärtnereien, Dissertation, TU München.

68. Speer, P.W. \& Hughey, J. (1995), Community organizing: An ecological route to empowerment and power, in: American Journal of Community Psychology, 23(5), 729748.

69. Schulte-Zurhausen, M. (2005), Organisation. Volume 4. München.

70. Spectrum.de; $\quad$ http://www.spektrum.de/lexikon/geographie/einzugsbereich/1946, 06.09.16

71. Taspo, Gartenbau-Adressbuch Nord und Süd, Thalacker, Braunschweig, 2010/2011.

72. Theobald, N.A. et al (2005), The many faces of span of control, Organizational Structure Across Multiple Goals, in: Administration \& Society, 36(6), 648-660.

73. Titscher, S., Meyer, M. \& Mayrhofer, W. (2008): Organisationsanalyse, Konzepte und Methoden, UTB, Wien.

74. Thompson, G.M., (1997), Labor staffing and scheduling models for controlling service levels, in: Naval Research Logistics, 44(8), 719-740.

75. Tröster, B. (2016), oral interview on July, 27th, 2016, Agrarmarkt InformationsGesellschaft mbH (AMI), Bonn.

76. Vahs, D. (2009), Organisation5, 43-46. Schäffer-Poeschel. Heidelberg.

77. Voigt, B.F. (2016), Understanding the conditions of separation for an integrated organizational setup: PSS divisional boundaries in the light of heterogeneity and duality theories, in: Procedia CIRP, 47, 276-281.

78. Von Allwörden, A. (2005), Untersuchungen zur Situation existenzgefährdeter Betriebe in Landwirtschaft und Gartenbau, -Ursachen, wirtschaftliche und soziale Folgen sowie Konsequenzen für die Beratung-, Dissertation. Berlin.

79. Wan, X., Evers, P. T. \& Dresner, M.E. (2012), Too much of a good thing: The impact of product variety on operations and sales performance, in: Journal of Operations Management, 30, 316-324.

80. Weiand, A. (2009), BWL in Fallstudien. Schäffer-Poeschel. Stuttgart.

81. Wernitz, F. (2015): Wissenschaftsmarketing, Grundlagen und Möglichkeiten am Beispiel der Ressortforschung, 100-107. Gabler, Wiesbaden.

82. Wong, K.Y. (2005), Critical success factors for implementing knowledge management in small and medium enterprises, in: Industrial Management \& Data Systems, 105(3), 261279.

83. Zentralverband Gartenbau e.V. (ZVG, 2017), Jahresbericht 2016, Berlin.

84. Zentrum für Betriebswirtschaft im Gartenbau e.V., (ZBG, 2014) in: ZBGBranchenbericht $\quad$ Einzelhandelsgärtnereien, http://www.zbg.unihannover.de/fileadmin/institut/zbg/pdf_downloads/Branchenberichte/Einzelhandelsgaert nereien.pdf2014.

85. Zentrum für Betriebswirtschaft im Gartenbau e.V. (ZBG, 2015) in: Kennzahlenvergleich für den Betriebsvergleich im Gartenbau, 58. 